Benchmark

\title{
Methylation Analysis of Formalin-Fixed, Paraffin-Embedded Sections Using a Nontoxic DNA Extraction Protocol
}

BioTechniques 31:1354-1357 (December 2001)

\section{Lor-wai Tan and Alexander Dobrovic \\ The Queen Elizabeth Hospital, Woodville SA, Australia}

DNA methylation is an epigenetic mechanism responsible for gene silencing (4). The methylation status of a gene can be assessed by a variety of methodologies $(1,7)$. These commonly involve sodium bisulfite treatment of genomic DNA that converts unmethylated, but not methylated, cytosine residues to uracils (2), followed by PCR amplification. We have adapted the basic bisulfite modification protocol specifically to examine methylation using DNA from formalin-fixed, paraffin-embedded tissue sections.

Formalin-fixed, paraffin-embedded sections have been extensively used as a source of genomic DNA for PCR-based analysis. A significant advantage associated with the use of paraffin sections is that they can be microdissected to enrich for subpopulations such as tumor cells, thus reducing the confounding effect of contaminating normal tissue that can complicate data interpretation. This necessitates efficient methodologies for isolating DNA from the very small numbers of cells present in these sections. The ability to extract DNA from paraffin sections allows the use of material for retrospective studies and understanding tumor evolution. In the first part of our methodology, we have developed an efficient, nontoxic protocol to prepare PCR-quality DNA from formalin-fixed, paraffin-embedded tumor sections. This protocol uses Histoclear ${ }^{\mathrm{TM}}$ (National Diagnostics, Atlanta, GA, USA) instead of xylene or octane for deparaffinizing the sections.

Ten-micron sections were prepared from paraffin-embedded blocks of formalin-fixed breast tumor biopsies. A hematoxylin and eosin-stained master slide was used as the template to outline the area of tumor tissue. Tumor tissue was microdissected by scraping with a sterile scalpel blade. Normal tissue was first removed, and then tumor tissue was transferred into a $1.5-\mathrm{mL}$ microcentrifuge tube to which $1 \mathrm{~mL}$ Histoclear had been added. The sample was mixed on a rotor (RMS 6; Ratek Instruments, Boronia, Victoria, Australia) at room temperature for $10 \mathrm{~min}$ and then centrifuged at $16000 \times g$ for $10 \mathrm{~min}$. The supernatant was removed, the pellet was resuspended in fresh Histoclear, and the rotary mixing and centrifugation were repeated twice.

The pellet was then sequentially rehydrated first in $1 \mathrm{~mL}$ absolute ethanol and then in $1 \mathrm{~mL}$ of $80 \%$ ethanol. On each occasion, the sample was mixed on the rotor for $10 \mathrm{~min}$, followed by centrifugation at $16000 \times g$ for $10 \mathrm{~min}$. After the removal of the supernatant, $200 \mu \mathrm{L}$ InstaGene ${ }^{\mathrm{TM}}$ matrix (Bio-Rad Laboratories, Hercules, CA, USA) and $80 \mu \mathrm{g}$ Proteinase $\mathrm{K}$ were added to the pellet and incubated for $16 \mathrm{~h}$ at $55^{\circ} \mathrm{C}$. The sample was then heated at $100^{\circ} \mathrm{C}$ for $10 \mathrm{~min}$ to inactivate the Proteinase $\mathrm{K}$, and the supernatant was collected after spinning at $16000 \times g$ for $15 \mathrm{~min}$.
The supernatant was extracted using phenol chloroform; $1 / 10$ volume of 3 $\mathrm{M}$ sodium acetate ( $\mathrm{pH}$ 5.2) was added to give a final concentration of $0.3 \mathrm{M}$. Two and a half volumes of absolute ethanol were added before an overnight precipitation at $-20^{\circ} \mathrm{C}$. The DNA was then spun at $16000 \times g$ for $30 \mathrm{~min}$, washed in $70 \%$ ethanol, air dried, and resuspended in $17 \mu \mathrm{L}$ Ultrapure ${ }^{\mathrm{TM}}$ water (Fisher Biotec, Perth, Australia).

In the latter part of the methodology, it was necessary to adapt the bisulfite conversion procedure for DNA extracted from formalin-fixed, paraffin-em bedded sections. The limited amounts of DNA required the use of carrier DNA and a co-precipitant $(3,5)$. Our previous protocol, which worked well with genomic DNA prepared by standard means, gave incomplete conversion with section-derived DNA. Accordingly, a more extensive denaturation protocol was adopted that involved the use of urea and repeated cycling up to $95^{\circ} \mathrm{C}(6)$.

Salmon sperm DNA ( $1 \mu \mathrm{g}$; Sigma, St. Louis, MO, USA) was added as a carrier to the isolated DNA (3). The DNA was denatured using $2 \mu \mathrm{L}$ freshly prepared $3 \mathrm{M} \mathrm{NaOH}$ in a final volume of $20 \mu \mathrm{L}$ and then incubated for $30 \mathrm{~min}$ at $37^{\circ} \mathrm{C}$. Then, $278 \mu \mathrm{L}$ of a $6.24 \mathrm{M}$ urea/4 $\mathrm{M}$ sodium bisulfite and $2 \mu \mathrm{L}$ freshly prepared $100 \mathrm{mM}$ hydroquinone (Sigma) were added. The solution was made by dissolving $7.5 \mathrm{~g}$ urea (Ajax Chemicals, Sydney, Australia) in $10 \mathrm{~mL}$ sterile water. This was followed by $7.6 \mathrm{~g}$ sodium bisulfite (Sigma) and then adjusting the $\mathrm{pH}$ to 5.0 with $10 \mathrm{M} \mathrm{NaOH}$ 


\section{Molecular Diagnostic Techniques}

and adding sterile water to a final volume of $20 \mathrm{~mL}$. The final concentrations of the urea, sodium bisulfite, and hydroquinone were $5.8 \mathrm{M}, 3.7 \mathrm{M}$, and 0.67 $\mathrm{mM}$, respectively. The DNA was subjected to 20 cycles of $55^{\circ} \mathrm{C}$ for $15 \mathrm{~min}$, followed by denaturation at $95^{\circ} \mathrm{C}$ for 30 $\mathrm{s}$ in a PTC-200 ${ }^{\mathrm{TM}}$ thermal cycler (MJ Research, Waltham, MA, USA).

The modified DNA was then desalted using CONCERT ${ }^{\mathrm{TM}}$ rapid $\mathrm{PCR}$ purification columns (Invitrogen, Carlsbad, CA, USA) according to the manufacturer's instructions. The bisulfite-modified DNA was eluted from the column using $50 \mu \mathrm{L}$ TE $(10 \mathrm{mM}$ Tris$\mathrm{HCl}, \mathrm{pH}$ 8.0, 0.1 mM EDTA) preheated to $55^{\circ} \mathrm{C}$. A desulfonation step followed where $5.5 \mu \mathrm{L}$ of $3 \mathrm{M} \mathrm{NaOH}$ was added to the $50 \mu \mathrm{L}$ eluate and the DNA was incubated at $37^{\circ} \mathrm{C}$ for $15 \mathrm{~min}$. One microliter of molecular biology-grade mussel glycogen (5 $\mu \mathrm{g} / \mu \mathrm{L})$ (Roche Molecular Biochemicals, Mannheim, Germany) was added to the sample as a co-precipitant. This was followed by $1 / 10$ volume of $3 \mathrm{M}$ sodium acetate and $2.5 \times$ volume of absolute ethanol. The sample was mixed and then precipitated at $-20^{\circ} \mathrm{C}$ for $16 \mathrm{~h}$ and spun at $16000 \times g$ for $25 \mathrm{~min}$. The pellet was then resuspended in $50 \mu \mathrm{L}$ Ultrapure water and stored at $4^{\circ} \mathrm{C}$ until used.

To validate this protocol, we used our previously developed methylationsensitive, single-strand conformation analysis (MS-SSCA) methodology (1). MS-SSCA is based on electrophoretic detection of sequence differences of bisulfite-modified DNA that has undergone PCR amplification. The PCR product is denatured to give single strands and then subjected to non-denaturing gel electrophoresis where it adopts sequence-dependent secondary structures (conformers) with different migration rates.

Primers were designed to examine the promoter methylation status of connexin 26. It was not possible to totally avoid $\mathrm{CpG}$ dinucleotides in the design of these primers, but they were placed as far $5^{\prime}$ in the primer sequence as was possible. We chose to maintain the $\mathrm{C}$ at $\mathrm{CpG}$ dinucleotides. This slightly favored the amplification of methylated sequences, but it should be noted that PCR amplification often favors the unmethylated sequence (8). A pair of primers [ $5^{\prime}-$ ATTCGGGAAGTTTTGAGGATTTA GAGGT-3' (sense) and 5'-GTTAAAATCTCTACGCTAAAACTCCTAC-3' (antisense)] was used to amplify a 245bp target fragment of the connexin 26 promoter region $\left(\mathrm{GenBank}{ }^{\circledR}\right.$ accession no. U43932) from bisulfite-modified DNA samples. PCR was performed in a final volume of $50 \mu \mathrm{L}$ using $5-10 \mu \mathrm{L}$ sodium bisulfite-modified DNA, $100 \mathrm{ng}$ each primer, $2 \mathrm{mM} \mathrm{MgCl}_{2}$, and $0.5 \mathrm{U}$ HotStarTaq $^{\mathrm{TM}}$ DNA polymerase in buffer supplied by the manufacturer (Qiagen, Valencia, CA, USA). The first cycle was preceded by an activation step of $95^{\circ} \mathrm{C}$ for $15 \mathrm{~min}$. Amplification was then performed for 45 cycles with an initial 10 cycles of $94^{\circ} \mathrm{C}$ for $1 \mathrm{~min}$, touchdown annealing temperature step from $72^{\circ} \mathrm{C}$ to $62^{\circ} \mathrm{C}$ for $45 \mathrm{~s}$ and $72^{\circ} \mathrm{C}$ for $45 \mathrm{~s}$, followed by 35 cycles of $94^{\circ} \mathrm{C}$ for $1 \mathrm{~min}$, $62^{\circ} \mathrm{C}$ for $1 \mathrm{~min}$, and $72^{\circ} \mathrm{C}$ for $1 \mathrm{~min}$. SSCA was carried out as previously reported (1). Briefly, the PCR product was denatured in freshly prepared loading buffer (95\% formamide, $10 \mathrm{mM} \mathrm{NaOH}$, $0.25 \%$ bromophenol blue, and $0.25 \%$ xylene cyanol) by heating at $95^{\circ} \mathrm{C}$ for 5 min and chilled on ice for $3 \mathrm{~min}$. It was then electrophoresed on a $0.75 \times \mathrm{MDE}^{\mathrm{TM}}$ polyacrylamide gel (BMA, Rockland, ME, USA), stained with SYBR ${ }^{\circledR}$ Gold (Molecular Probes, Eugene, OR, USA) and visualized on a transilluminator (TVD 1000 R/F; Spectronics, Westbury, NY, USA) (Figure 1).

In this communication, we have a new protocol for the preparation of DNA suitable for PCR amplification from formalin-fixed, paraffin-embedded tissues and have adapted the bisulfite conversion procedure. Current methodologies for the extraction of DNA from paraffin-embedded sections use highly flammable and carcinogenic solvents such as xylene or octane in the initial deparaffinization step. We used Histoclear in the deparaffinization step to avoid exposure to these highly carcinogenic organic solvents. The procedure can be safely performed without the use of a fume hood. Histoclear, a plant-derived alkyl hydrocarbon, has been classified as safe by the US Department of Labor. Histoclear has a further advantage in that it facilitates the formation of a visible pellet after centrifugation, thus minimizing the loss of tumor tissue on aspiration, unlike $x y$ lene where tissue fragments remain afloat in the solvent. To our knowledge, this is the first report of the use of Histoclear to prepare DNA from paraffinembedded sections for DNA analysis.

We used InstaGene during the Proteinase $\mathrm{K}$ digestion of DNA from formalin-fixed, paraffin-embedded sections. InstaGene is a Chelex ${ }^{\circledR}$-type biotechnology-grade resin specially formulated for the purpose of preparing genomic DNA for PCR. It functions to remove inhibitors of PCR amplification. Nevertheless, we found it necessary to include a subsequent phenol chloroform extraction step to improve the yield of PCR product (results not shown).

The quality of modified DNA is suitable for methylation studies. We were routinely able to amplify DNA from a single $10-\mu \mathrm{m}$ section using the technology described above. Furthermore, we were able to extract PCR-quality DNA from sections that other laboratories had found to be refractory to amplification using xylene-based protocols. We thus carried out a comparative MSSSCA study using Histoclear and xy- 


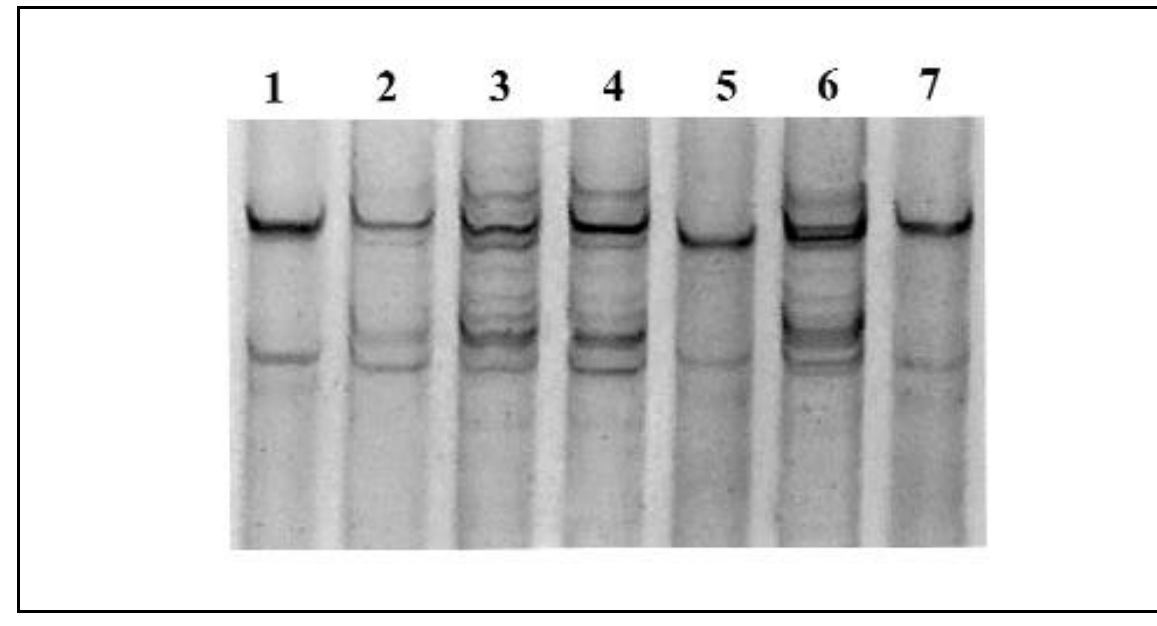

Figure 1. MS-SSCA of Cx26 promoter from paraffin-embedded section of breast tumors. DNA extracted from paraffin-embedded sections from seven breast cancer patients were sodium bisulfite-modified, PCR amplified, and electrophoresed on an MDE gel as described in the text. (Figure is an inverse image.)

lene on paraffin sections using five unselected patient sections. Except for the solvent, the adopted protocol was performed as described above. Where Histoclear was used, amplification of the correct size product of 245 bp was detected in the sodium bisulfite-modified DNA from all patients. By contrast, when xylene was used, amplification was observed only for four patients. MS-SSCA of the PCR product from Histoclear and xylene-extracted, sodium bisulfite-modified DNA of this patient revealed no difference in banding patterns (results not shown). It is thus clear that not only is Histoclear a less toxic alternative to xylene but it may be more reliable in producing amplifiable DNA. We have now been able to extract PCR-quality DNA from 50 of 54 (93\%) paraffin-embedded breast tumor sections ranging in age from a few weeks to seven years old.

We overcame the problem of having only limited amounts of genomic DNA by amending our bisulfite modification protocol. First, we used salmon sperm DNA as a carrier during the initial bisulfite conversion step (3). Also, to reduce the loss of DNA after modification, molecular biology-grade glycogen was added as a co-precipitant (5). As the extracted DNA was in some instances not completely converted in the bisulfite modification step, we have also included in our MS-SSCA protocol the use of high urea concentrations and repeated thermocycling to maintain single-strand separation and aid conversion (6).

The use of CONCERT rapid PCR purification columns significantly reduced the time required and simplified the desalting of samples after bisulfite conversion. In comparison, previously reported desalting methodologies were more complex and time consuming $(2,3,6)$.

Figure 1 shows banding patterns of individual patient breast tumor samples. Lanes 1, 5, and 7 show a pattern typical of an unmethylated sequence. Lanes 2, 3, 4, and 6 are methylated with little or no normal pattern, as would be expected from microdissected tumor samples. Variant bands were stabbed and sequenced to verify the complete conversion of unmethylated cytosines to thymines from DNA extracted from ingly, there is a complexity of methylation, especially in the latter three samples. This level of complexity was not observed by us in bulk DNA from tumor samples and may indicate that the analysis of paraffin sections may more accurately reflect tumor heterogeneity.

\section{ACKNOWLEDGMENTS}

The authors thank Drs. Karen Riches and Wendy Lew (Dept. Histopathology, The Queen Elizabeth Hospital) for providing paraffin sections and A/Prof. Ed Sage for his continuing support, Dr. Damian Hussey, Dr. Sally Stephenson, paraffin-embedded sections. Interest-
Ms. Tina Bianco, and Ms. Tanya Sanders (Dept. Haematology-Oncology, The Queen Elizabeth Hospital), and Ms. Kathy Cox (Dept. Molecular Pathology, Institute of Medical and Veterinary Science, Adelaide) for technical advice. L.T. is supported by the Esther Caldwell Cook Postdoctoral Research Fellowship and The Queen Elizabeth Hospital Research Foundation. This work was funded in part by grants from the National Health and Medical Research Foundation and The Queen Elizabeth Hospital Medical Research Foundation.

\section{REFERENCES}

1.Bianco, T., D. Hussey, and A. Dobrovic. 1999. Methylation-sensitive, single-strand conformation analysis (MS-SSCA): a rapid method to screen for and analyse methylation. Hum. Mutat. 14:289-293.

2.Frommer, M., L.E. McDonald, D.S. Millar, C.M. Collis, F. Watt, G.W. Grigg, P.L. Molloy, and C.L. Paul. 1992. A genomic sequencing protocol that yields a positive display of 5methylcytosine residues in individual DNA strands. Proc. Natl. Acad. Sci. USA 89:18271831.

3.Herman, J.G., J.R. Graff, S. Myohanen, B.D. Nelkin, and S.B. Baylin. 1996. Methylationspecific PCR: a novel PCR assay for methylation status of $\mathrm{CpG}$ islands. Proc. Natl. Acad. Sci. USA 93:9821-9826.

4.Jones, P.A. and P.W. Laird. 1999. Cancer epigenetics comes of age. Nat. Genet. 21:163-167.

5.McDonald, L.E. and G.F. Kay. 1996. Methylation analysis using bisulphite genomic sequencing: application to small numbers of intact cells. BioTechniques 22:272-274.

6.Paulin, R., G.W. Grigg, M.W. Davey, and A.A. Piper. 1998. Urea improves efficiency of bisulfite-mediated sequencing of 5'-methylcytosine in genomic DNA. Nucleic Acids Res. 26:5009-5010.

7.Rein, T., M.L. DePamphilis, and H. Zorbas. 1999. Identifying 5-methylcytosine and related modifications in DNA genomes. Nucleic Acids Res. 26:2255-2264.

8.Warnecke, P.M., C. Stirzaker, J.R. Melki, D. Millar, C.L. Paul, and S.J. Clark. 1997. Detection and measurement of PCR bias in quantative methylation analysis of bisulphite-treated DNA. Nucleic Acids Res. 25:4422-4426.

Received 11 December 2000; accepted 20 July 2001.

\author{
Address correspondence to \\ Dr. Alexander Dobrovic \\ Department of Haematology-Oncology \& \\ University of Adelaide Department of \\ Medicine \\ The Queen Elizabeth Hospital \\ Woodville SA 5011, Australia \\ e-mail: alexander.dobrovic@adelaide.edu.au
}

